EREM $77 / 3$

Journal of Environmental Research, Engineering and Management Vol. 77 / No. 3 / 2021 pp. 32-49

DOI 10.5755/j01.erem.77.3.29230
Understanding Drivers of Renewable Energy Firm's Performance

Received 2021/06

Accepted after revision 2021/08

\title{
Understanding Drivers of Renewable Energy Firm's Performance
}

\section{Fatbardha Morina*}

Assistant Lecturer, Epoka University

\section{Uğur Ergün}

Lecturer, Epoka University

\section{Eglantina Hysa}

Lecturer, Epoka University

*Corresponding author: fmorina@epoka.edu.al

The purpose of this study is to identify the drivers of profitability for renewable energy companies in the European Union (EU) during the period of 2004-2018. Specifically, the study investigates the effect of firm-specific, country-specific, and macroeconomic factors on the profitability of the listed renewable energy companies that have their headquarters in the EU. The profitability is measured as return on assets (ROA) and Tobin's q. Factors that affect profitability are divided into three groups such as firm-specific, country-specific, and macroeconomic factors, and to provide consistent and unbiased results, distinct methods are used. The ordinary least square (OLS) and random effect Generalized Least Squares (GLS) model are employed first. Also, the two-step system generalized method of moments estimation is used to validate the hypotheses. The empirical findings show that firm-specific factors are more dominant in explaining profitability rather than macroeconomic factors. The dynamic models show that profit persists over the years. Also, it is revealed that firm size has a positive effect on profitability in all models. The hypothesis that firms' growth enhances profitability is evident in the short run, but in the long run, it is insignificant. The leverage has a positive effect on Tobin's q. In addition, the study finds that tradable green certificate schemes enhance long-term profitability (Tobin's q). The financial crises discourage the financial performance of renewable energy firms. The study has implications for managers and policymakers that should give importance to firm-specific factors and country-specific 
factors to promote the profitability of renewable energy companies in order to be sustainable by reducing energy import dependency and ensure energy for the future generation. Special attention should be given to support schemes toward renewable energy to be more effective and enhance firm profitability. The contribution of this paper is that it is the first study that examines the drivers of profitability for renewable energy companies by accounting for firm-specific, country-specific and macroeconomic factors. The study includes a long-time period by using advanced panel data techniques. To add robustness, alternative measures of profitability are used.

Keywords: ROA, Tobin's q, renewable energy, profitability, dynamic model.

\section{Introduction}

The development of renewable energy has aroused the attention of governments in terms of energy production and consumption. The role of the renewable energy sector is fundamental in the economy because of the significant contribution that renewable energy can make towards improving economic growth, mitigate pollution in the environment and energy security for the future generation. Using renewable energy sources to generate renewable energy is becoming an integral part of climate and energy policy worldwide. Under the energy union strategy, EU member states have agreed on targets to ensure clean energy. The share of renewable energy during 2017 was $17.52 \%$ against a target of $20 \%$ for 2020 , which means that the EU is on track to achieve this target (European Commission, 2019). The establishing of these policies towards getting the market share and shifting from fossil fuels to renewable sources are encouraged by involving renewables in all five dimensions of the Energy Union such as energy security, the internal energy market, energy efficiency, decarbonisation of the economy, research, innovation, and competitiveness. Moreover, for the period of 20092018, the cost of electricity from solar photovoltaic (PV) and wind power is falling more rapidly than those of fossil fuel-based electricity sources. Much of the progress in the reduced cost of renewable electricity comes from the support schemes in the sector, advances in efficiency, capital cost reduction and improvement of supply chain management. Thus, in recent years, the renewable energy sector has experienced rapid investment growth to achieve emission reduction targets and to mitigate greenhouse gas emission through the support of different fiscal and financial policies. Corporate social responsibility not only upsurges profitability but also increases non-financial performance such as customer satisfaction and the efficiency of internal business processes (Mishra and Suar, 2010). The concern related to energy supply security and environmental issues enhances the development of renewable energy. Investment in renewable energy plays a vital role in the European Union (EU) because there is a shortage of energy security and high-energy import dependency. Replacing fossil fuels with renewable energy is environmentally friendly, taking into account that energy is produced by using local natural resources, which are continuously replenished and aim to reduce the need for importing fossil fuels and electricity that contribute to energy security at the EU level (Gökgöz and Güvercin, 2018)then benchmarks the performance of the selected EU countries in RE efficiency and productivity from 2004 to 2014 with a perspective of energy security. The results of the super-efficiency model of data envelopment analysis (DEA. Thus, the sustainable development of the renewable energy sector, supported by innovation (Hysa et al., 2020), requires long-term action, and usage of renewable energy resources seems to be the most effective and efficient way of tracking environmental issues (Ruggiero and Lehkonen, 2017). Apart from sources that have a minimal environmental impact, sustainability relies on the social level to provide access to reliable and affordable energy supplies. Thus, to combat energy insecurity and mitigate climate change, the profitability of renewable energy (RE) firms is fundamental for their sustainability.

Most of the prior studies analyzed the trade-off between environmental investment and financial performance of electric utilities rather than determinants of profitability (Filbeck and Gorman, 2004; Sueyoshi and Goto, 2009; Leitão and Balsalobre-lorente, 2021). By now, studies that analyze factors affecting the financial performance 
of energy firms are lacking. The profitability of renewable energy firms has a central role in their sustainability, economic goals and environmental aspects. Additionally, the profitability of green energy is affected by a number of factors, such as uncertainty in the energy market, cost, and frequent changes in the support schemes (Cucchiella, Gastaldi and Trosini, 2017). Although the development of green energy has led to falling prices and reducing costs, the aim of this study is to provide evidence on the drivers of the profitability in renewable energy companies in EU member states because the EU has experienced rapid growth of green energy and tends to be a leader in renewable energy production, especially in the wind power and solar PV sectors. The renewable energy sector in the $\mathrm{EU}$ is crucial to ensure clean energy since EU countries have dependency on energy imports, and the financial performance of these companies is affected by various factors (Pacesila et al., 2016). In this research, ordinary least squares (OLS), random effect (RE), and dynamic panel model GMM are used to study the drivers of profitability in renewable energy companies for the period spanning from 2004-2018.

This research provides insights into factors that boost the financial performance of renewable energy companies in the EU. The company's profitability contributes to the overall wellbeing of the economy and ensures its sustainability. The main contribution is that this study provides insights for policymakers, regulators, and investors in order to understand the main channels that affect renewable energy firms' performance. Furthermore, this study investigates how firm-specific, country-specific, and macroeconomic factors affect the profitability of renewable energy companies. The empirical results highlight that firm size has a positive and significant impact on profitability, implying that large firms have higher return on assets (ROA) and Tobin's q.

The rest of the paper is organized as follows: the literature review section provides an overview of the related literature in the sources of the variation in firm profitability. In the methods section, the empirical framework and estimation methods are discussed. The results and discussion section describes the results from regression models. In the final section, we discuss the findings and present the conclusions.

\section{Literature Review}

Financial performance is a key indicator for firms to survive in the market and also for investors that want to invest in it. Profitability is considered as an indicator of progress and improvement in order to provide sustainability in the near future. In the theoretical literature, there are two opposite views concerning the determinants of profitability. According to the first view, structural conduct performance (SCP), market concentration is the key determinant of profitability for firms. Thus, the SCP relationship is examined by a large number of empirical studies, based on pioneering work of Bain (1951), which reveal that industry structure in terms of industry concentration and entry barriers determine the potential performance. The latter implies that firm-specific factors are fundamental for their performance. The resource-based view suggests that the difference on profit among firms within the same industry is explained by the internal factors of each firm (Barney, 1991). The study by Spanos et al. (2004) states that the heterogeneity of company performance is explained more than twice by firm-specific factors than industry-specific factors. Most empirical studies over the last two decades have focused on the relationship between environmental and financial performance for renewable energy companies (Wang, Li and Gao, 2014; Ruggiero and Lehkonen, 2017). But the question is whether in order to be sustainable to provide clean energy for future generations with affordable prices these companies are profitable? Paun (2017) examines the financial performance of energy firms and concludes that renewable energy companies have poor financial performance since they face financial difficulties due to changes in the subsidy program. In addition, the energy transformation differs among EU states. In Central and Eastern European (CEE) countries, there is a "delay" in the process of energy transformation compared with Western European states, due to historical conditions, but being a member of the European Union structures has fostered the development of green energy under the strategic place of energy policy. Thus, the development of green energy in this region is affected by their climatic conditions and their resources. Government support is a key factor that has intensified the energy transformation and 
enhanced new investment in renewable energy sources (RES) (Pakulska, 2021). Marian and Panait (2019) state that the support from the government has certain benefits, such as the development of communities, environmental protection, and elimination of the distortions to the energy market that is obviously dominated by the traditional producers. In addition, the study by Abbasi et al. (2020) observes that the policies that rely on renewable energy sources enhance economic growth and keep the environment clean. The drivers of profitability are grouped into firm-specific factors, country-specific factors, and macroeconomic factors.

\section{Firm-specific effects}

Goddard, Tavakoli and Wilson (2009) present evidence that firm-specific and the corporate group effects comprise the main source of contribution to profitability. By using variance decomposition analysis of firm-level profitability, they support the previous empirical studies that the organization structure and management practices at the firm or being part of a larger corporate group are the main sources of variation of profitability between firms.

Related to firm-specific factors, authors claim on different factors as determinants of profitability. Kogan and Tian (2012) state that firm size, asset growth, leverage, sales growth, turnover, and liquidity are the most important firm characteristics. Other authors consider board size, ownership structure, age of the firm, and dividend payment as internal factors that determine profitability (Wintoki, Linck and Netter, 2012; Phung and Mishra, 2016).

In most empirical studies, the crucial role of firm size is mentioned, and authors reveal mixed results on the effect of a firm size such as positive, negative, and no impact. Firm size allows firms to use different data management strategies to take competitive advantages in the market that contribute to governmental benefits and profitability. Large firms that are more visible follow strategies that reduce the company's environmental effects. In contrast, small firms are more oriented to survive in the market. The environmental initiative commitment of large firms is related to opportunities to access finance and superior resources. In contrast, small firms face finance constrain that affects green investment. According to Apergis and Sorros (2014), RandD for renewable energy firms ensure a higher value-added in the sold renewable energy.
These firms are characterized by technological innovations that are supported by the firm size that in turn upsurges profitability. In the same line, Fareed et al. (2017) conclude that firm size enhances the financial performance of energy firms. However, Lin et al. (2019) state that firm size influences green investment strategies that moderate the relationship between green investment and financial performance. Also, the study by Li et al. (2021) shows that the corporate social responsibility (CSR) initiatives along with workplace autonomy are very helpful in creating an innovative employee behaviour that brings financial benefits through profit margins, business efficiency, and product life cycles.

Leverage is another factor that affects profitability. The study by Akhtar et al. (2012) shows that financial leverage improves financial performance for firms that have higher profitability. In contrast, Mohamed (2014) studies the financial performance of 30 American energy firms during the period of 2005-2013 and concludes that leverage and size in terms of sales negatively influenced the performance. Only the short-term debt enhances financial performance. Similarly, Apan and İslamoğlu (2018) investigate the linkage between financial ratio and financial performance of 10 listed energy firms for the period 2008-2015 and state that leverage has a negative effect on profitability, while sales growth and liquidity ratio improve financial performance. Chadha and Sharma (2015) study the nexus between leverage and financial performance for 422 listed manufacturing companies in India during the period of 2003-2013 and conclude that leverage has no impact on financial performance proxies such as return on asset and Tobin's q, but it has a negative effect on return on equity. Capece et al. (2012) study the natural gas market in Italy by investigating the impact of age, size, and regulatory intervention in profitability. They conclude that the financial performance of newly formed firms is the worst since they continue not to be very competitive in the market. Also, small firms face a lack of finance and difficulties to find a client and are more domestic oriented. However, the study by Neves et al. (2019) shows that the effect of leverage on the financial performance of electricity firms that operate in Portugal seems to be positive during the year 2010, but not in 2014, and that it is needed to take action to reduce the level of debt. In the same line, Ali and Alam 
(2021) show that the difference in the profitability among firms that operate in the energy sector in Saudi Arabia is affected mostly by internal factors. They find that a high debt-to-equity ratio is favorable during the growth phase, while during the recession period a reduction of debt-to-equity ratio is suitable.

Furthermore, Seissian et al. (2018) conclude that the financial performance of listed companies is affected by credit ratings. A credit rating that reflects default risk is an assessment of an entity's ability to pay its financial obligations and firms that are upgrades in their credit ratings have higher profitability. Credit policy and financial constraints have a significant contribution to renewable energy firm's performance. Those firms that have richer liquid assets and commercial credit encourage renewable energy investment opposite to the other firms that are highly bank dependent, and more long-term debts may reduce their tangible investment (Chang et al., 2019).

\section{Country effects}

The financial performance of renewable energy is strongly connected with country-specific factors. Do policies followed by the government promote energy generation from renewable energy sources (RES)? Electric utility firms produce not only bad goods that cause air pollution but also good products. Apart from environmental regulation for bad products, electric utilities face some regulation for good products such as entry regulation, revenue regulation, retail price regulation of electricity, and transmission control (Sueyoshi and Goto, 2009). Thus, the additional cost related to good products must face financial difficulties to produce green electricity, and financial support from local government is necessary. The ambitious renewable energy targets could be achieved with the help of new regulations that encourage the development of business models that promote generation, transmission and sales of renewable energy (Richter, 2013). Since in their infant stages they require higher capital investments, the support mechanisms from public authorities such as feed-in tariffs (FIT) and tradable green certificates (TGC) are crucial to help them to grow to maturity. The FIT mechanism is a form of subsidy that guarantees a certain price for a long period since these projects have a durability of 20-30 years. In contrast, TGC is a regulatory intervention by the government that gives certification for the amount of energy that is generated from green sources. The quantity restriction introduced by the TGC systems is determinant for the market price of renewable electricity (Verbruggen and Lauber, 2012) However, among the authors, there is a wide debate when comparing renewable energy support mechanisms to promote renewable energy. According to Agnolucc (2007), investors that produce renewable energy in the case of the TGC systems might face the uncertainty price of the green certificate that makes this investment riskier due to capital constraints. Contrary, firms that operate under FIT systems access cheaper capital. Hence, the TGC market that faces capital constraints requires a high level of returns that may result in higher market concentration. In the same line, Jaraite and Kažukauskas (2013) conclude that electric utility firms that operate in the EU and have implemented TGC are more profitable compared with FIT firms. Also, countries that invest in a high level of technology and innovation are more likely to foster the development of renewable energy and to enhance their profitability (Gupta, 2017). However, the study by Zhang et al. (2014) examines the effect of subsidies in the financial performance of renewable energy manufacturing companies listed on Shanghai and Shenzhen stock exchange during the period of 2007-2010 and reveal mixed results. They conclude that government subsidies have a positive effect on the financial performance of wind energy firms, but the effects become insignificant for solar energy companies. The financial performance of renewable energy companies is strongly related to government subsidies since they require a high capital investment, which cannot be recovered in the first years. The changes in the subsidy program after a few years could be very harmful to financial performance (Paun, 2017). Sun et al. (2020) examine the effectiveness of value- added tax incentives on new energy industry performance for companies listed in stock exchange in China. The study shows that the financial performance of new energy companies measured by return on equity (ROE) declines under the support of value-added tax (VAT) incentives. These results are related to the distorted industrial chain, overcapacity and low expenses in research and development. Khan et al. (2020) investigate the effect of renewable energy consumption on environmental quality for the period of 2001-2018 in Nordic countries. They find that policies to promote renewables are crucial for economic growth and environmental sustainability. 


\section{Macroeconomic factors}

The last group of factors that determine profitability is macroeconomic factors that include inflation rate, unemployment, gross domestic product (GDP), stock market index, corporate tax rate, and interest rate that are not under the control of management (Broadstock et al., 2011). The effect of economic and business cycles across time cannot be eliminated but at least the negative effects may be reduced by developing strategies to deal with economic falling (Issah and Antwi, 2017). The studies by Chang et al. (2009) and Kumar et al. (2012) reveal that income level has a significant contribution to renewable energy development. They note that countries with high economic growth increase renewable energy usage, while countries with a low economic growth rate do not have the capacity to invest in renewable energy in order to mitigate the negative effect of energy price increases. Similarly, Malik et al. (2014) find that GDP and inflation positively contribute to renewable energy consumption. However, the study by Zhu (2012) using data during the period of 2005-2011 for energy firms listed in Shanghai stock market concludes that GDP and inflation are not statistically significant for their financial performance. In concern to macroeconomic factors, Rashid (2013) and Barakat et al. ( 2015) opine that macroeconomic uncertainty influences the firm's capital structure decision more than firm-specific uncertainty. Also, the study by Shah et al. (2018) mentions that the effect of macroeconomic factors on renewable energy investment is more severe for countries with low support for the renewable energy sector. For these countries, financial support should be increased when oil prices are low, or the economy is in a downturn to ensure the sustainable development of renewable energy.

As it can be seen, there is a lack of studies that assess the financial performance of renewable energy companies by analyzing not only the effect of firm-specific factors but also country-specific factors and macroeconomic factors. The main contribution in the literature is related to the fact that this study provides evidence on the determinants of profitability for the firm level in the renewable energy sector that sheds light on this issue. Also, by taking into consideration the effect of policy effects on firm profitability, it enhances the reliability and credibility of the study.

\section{Methods}

\section{Data collection and samples}

This study includes companies that operate in renewable energy for the period ranging between 2004-2018. After excluding those firms, with data available for only the last three years, the final sample includes 41 listed renewable energy firms, which have their headquarters in the European Union countries. The analysis relies on renewable energy utilities and their respective electricity-generating technologies. The company-level financial data are obtained from Thomson Reuters Eikon. The consolidated financial statements standardized in US dollars are used in this study. GDP growth and inflation data are obtained from the World Bank DataBank. The data of industrial electricity prices without taxes charged in Euro per kWh are obtained from Eurostat. Also, Eurostat is used to gather the data of market concentration as a ratio of the largest generator in the electricity market as a percentage of the total electricity generation. The information related to the firms under TGC or FIT mechanism support scheme is obtained using the report of the Renewable Energy Sources country profile (CEER, 2017) To avoid the influence of outliers on the regression results, the data is winsorized at 99 percentiles. The choice of the renewable energy sector is related to the fact that they play a crucial role in sustainable development. The results of the study include a large time dimension compared with other studies, which can result in different findings.

\section{Definition of variables and measurement}

\section{Financial performance}

Many researchers have used several measures to represent financial performance, such as ROA, ROE, ROI, Tobin's q, EBIT margins (Earnhart and Lizal, 2007; Pätäri et al., 2014; Nanda and Panda, 2018). In this study, the financial performance of the firm is measured by using ROA as an accounting-based performance measure, and Tobin's q as a market-based measure. Return on assets (ROA) is a common measure for the firm's financial performance that represents the ability of the firm to generate earnings by using the total assets of each firm. Tobin's $q$ is used also as an alternative measure to estimate financial performance from different perspectives. Tobin's $q$ is used as a theoretically based measure of economic 
return and is the ratio of the market value of assets to their replacement cost and is crucial in the investment decision (Tobin, 1969). A value of Tobin's q greater than 1 for a firm shows that the present value of net profit is sufficient to keep the market value above the book value of total assets, and it can be considered a good investment opportunity (Lindenberg and Ross, 1981).

\section{Firm-specific factors}

\section{Size}

Firm size is an indicator that is considered deterministic in financial performance. This gives firms the opportunity to grow that benefit from economies of scale and earn higher profits. A variety of studies use the natural logarithm of total assets as a measure of firm size (Sueyoshi and Goto, 2009), while Pätäri et al. (2014) use annual sales and Nishitani and Kokubu (2012) use the natural logarithm of the number of employees as a proxy for firm size. In this study, the natural logarithm of market capitalization is used as an indicator variable for the size, since all firms are listed on the stock exchange and it represents the market value of the company.

\section{Risk}

The debt structure is the source of financial risk that is affected by the monetary policy changes and management decisions concerning the source of financing. Monetary policy changes affect the size of the external financial premium and reduce the expected future profits. In addition, the effect of monetary policy plays a vital role in a renewable energy firms' decision related to their capital structure and financial constraints. Having more liquid assets leads to renewable energy firms having the opportunity to borrow in commercial banks and to acquire external funds due to their ability to repay debts. Renewable energy firms that have high tangible assets are able to alleviate the effect of financial constraints on their financial performance during periods of contractionary monetary policy (Chang et al., 2019). Risk is calculated as the ratio of the total debts to the total assets in accordance with McWilliams and Siegel (2000) and Ruggiero and Lehkonen (2017) Other studies use firms' Beta as a proxy for risk.

\section{Age}

In the literature, the relationship between age and financial performance is still ambiguous. Firm's age is used to control the level of experience in the electricity sector. Renewable energy firms are relatively young, and older firms have facilities to borrow and to invest intangible assets. However, new firms can invest in new, more efficient technologies that might result in higher profits (Jaraite and Kažukauskas, 2013).

\section{Capital intensity}

Several authors have concluded that renewable energy firms require a high level of capital investment since their activity is related to investment-intangible assets. Thus, capital intensity is measured as capital expenditure divided by sales. The increasing capital intensity is related to the reduction of direct costs (Wang, Li and Gao, 2014). The natural logarithm of capital intensity is used.

\section{Growth}

The growth of the firm is related to a specific stage of its development and can be treated as an influential indicator of financial performance (Geroski et al., 1997). In line with Ramezani et al. (2002), the annual growth rate of sales is used as a proxy for firm growth.

Therefore, based on theoretical and empirical literature, the hypotheses to be tested are as follows:

H1. A firm's size positively affects its profitability.

H2. A firm's risk positively affects its profitability.

H3. A firm's age implies lower resource constraints, which positively affects its profitability.

H4. A firm's capital intensity positively affects its profitability.

H5. A firm's growth positively affects its profitability.

\section{Country-specific factors}

\section{Annual change in electricity price}

Energy generated from renewable energy sources is influenced by energy prices. The volatility of fuel prices has a significant effect on the sources of fuels that firms use to produce energy, which will reflect on the price of energy produced. The price of energy is associated with energy demand that affects firm profitability. However, energy price risk is the most important risk that can affect renewable energy investments and is the primary target of states' policymakers to control the volatility of energy prices. Since it is difficult to find multiple fuel prices for each country and firm-level, it is suggested to use the price of electrical energy for 
industrial customers in EU member states. This indicator presents the electricity price without taxes and levies for non-household consumers. A similar strategy is suggested by Anderson, Di Maria and Convery (2011), which uses the natural logarithm of electricity prices. The expected effect of the electricity price is positive on renewable energy consumption, therefore, enhancing profitability since a higher electricity price makes renewable firms more feasible and more competitive.

\section{Market concentration}

An indicator that describes the electricity market is the market share of the largest generation in the electricity market as a percentage of the total electricity generation. EU member countries have a common energy policy, but the electricity market differs among countries in terms of regulation and market structure.

\section{Support schemes}

EU countries have introduced various policies to increase the share of renewable energy production in total energy production, but the most popular support schemes are tradeable green certificate (TGC) and feed-in tariffs (FIT). To examine the effect of RE support schemes on profitability, a dummy variable is used. TGC dummy variable is equal to one for firms that operate in countries that adopt the TGC support mechanism and zero for other countries. The hypothesis related to country-specific factors are:

H6. There is a positive relationship between electricity prices and profitability.

$H 7$. There is a positive relationship between market concentration and profitability.

H8. There is a positive relationship between support schemes and profitability.

\section{Macroeconomic factors}

The effect of macroeconomic factors is unavoidable in the market. The most relevant factors included in the analysis are financial crises, GDP growth, and inflation.

\section{Financial crisis}

The global financial and economic crises have interrupted the growth path in all sectors including the renewable energy sector. To capture the influence of the financial crisis on profitability, it is divided into two subperiods. The pre-crisis period represents the period between 2007-2009 and the post-crisis represents the period over 2010-2012.

\section{Annual GDP growth rate}

The impact of income level on the development of renewable energy is expected positive since countries that are characterized by a high level of economic growth can implement sustainable and environmental policies to foster RE (Lester and Lombard, 1990).Also, high-economic growth countries can manage energy price impact better than low-economic growth countries. Developed countries can respond to energy price impacts by increasing renewable energy usage because they afford installation costs easier than low-economic growth countries can (Chang et al., 2009). The annual GDP growth rate is used as a proxy for the business cycle.

\section{Inflation}

A proxy for the inflation rate is consumer price index (CPI). The nexus between inflation and profitability may be positive or negative depending on how mature is an economy to forecast the expected inflation, and thus the firms begin to manage their operating costs. Molyneux and Thornton (1992) state that there is a positive relationship between inflation and profitability.

\section{Empirical model}

The system generalized method of moments (GMM) proposed by Arellano and Bover (1995) and Blundell and Bond (1998) is used in this study. This estimator includes the lagged dependent variable in the model to study the persistence of profitability if the past profitability determines the current profitability. The past profitability included in the model may be correlated with the unobserved and observable factors that could provide inconsistent and biased estimators in case that the problem of endogeneity is not overcome. OLS and fixed effects estimator neglect the unobserved time-invariant firm effects that lead to a biased estimator. Since the model includes a time-invariant policy variable, the fixed-effect model eliminates all variables that are time invariant, such as support schemes. On the other hand, the random-effect model is the appropriate model, when dummy and time-invariant variables are included, but it does not control for possible omitted variables. The literature discusses the persistence of profit in firm profitability if the past realization affects the actual firm profitability. The pattern of the dynamic panel model is employed 
to estimate the persistence of profit over time. The GMM estimator is used in case of the following: 1) fewer time periods and large individuals; 2) the dependent variable dependency on past realization; 3) possible independent variable correlation with past and current error term; and 4) heteroskedasticity and autocorrelation within individuals. In the dynamic panel model, GMM controls for the endogeneity of the lagged dependent variable when there is a correlation between explanatory variables and error term in the model, omitted variable biased, and unobserved panel heterogeneity. Compared with fixed (OLS) or random (GLS) models of panel data estimator, system GMM yields a more efficient and consistent estimator since it deals with possible endogeneity issues.

Table 1. Descriptive statistics

\begin{tabular}{c|c|c|c|c|c}
\hline Variable & Obs & Mean & Std.Dev. & Min & Max \\
\hline ROA & 565 & -0.033 & 0.164 & -0.689 & 0.313 \\
\hline Tobin's q & 521 & 1.359 & 3.115 & -0.930 & 26.517 \\
\hline Size & 527 & 11.723 & 1.823 & 7.305 & 16.332 \\
\hline Risk & 589 & 0.293 & 0.221 & 0 & 0.77 \\
\hline Age & 589 & 16.221 & 13.654 & 0 & 65 \\
\hline Capital intensity & 532 & -2.14 & 2.415 & -8.645 & 5.005 \\
\hline Growth & 543 & 1.094 & 4.912 & -0.965 & 38.245 \\
\hline TGC & 590 & 0.249 & 0.433 & 0 & 1 \\
\hline Electricity price & 583 & -2.265 & 0.25 & -2.777 & -1.783 \\
\hline Market concentration & 489 & 0.461 & 0.23 & 0.153 & 0.916 \\
\hline GDP growth & 590 & 0.015 & 0.023 & -0.056 & 0.060 \\
\hline Inflation & 590 & 0.017 & 0.012 & -0.008 & 0.049 \\
\hline D1 & 590 & 0.203 & 0.403 & 0 & 1 \\
\hline D2 & 590 & 0.208 & 0.407 & 0 & 1 \\
\hline
\end{tabular}

The general model of first-order autoregressive panel data that generate the process of system GMM estimator is given as:

$$
\begin{gathered}
y_{i t}=\alpha y_{i, t-1}+\theta X_{i t}^{\prime}+\mu_{i t} \\
\mu_{i t}=\eta_{i}+v_{i t}
\end{gathered}
$$

Where: $X_{i t}^{\prime}$ - is the vector of explanatory variables; $\mu_{i t}-$ is the disturbance term that includes time-invariant unobserved firm effect $\eta_{i}$ and error term that varies with individual and time $v_{i t}$.

The rule of thumb of thee dynamic panel system GMM is that all the data should be stationary. The augmented Dickey-Fuller (ADF) panel unit root test for each variable shows that there is enough evidence to reject the null hypothesis of the presence of unit root in the data. All the data are stationary in level. The consistency of system GMM relies on the hypothesis that there is no second-order serial correlation. Another important indicator that shows that the estimator is consistent is the number of instruments. According to Arellano and Bond (1991), the test of over-identifying restrictions is the Sargan test that shows that the instrument variables are not correlated with the error term. Also, the Hansen test shows the validity of instruments in the model by checking the $p$ value and failure to reject the null hypothesis of the validity of instruments. The efficient weight matrix that leads to asymptotic standard errors and results in a consistent estimator is used in this study as is suggested by Windmeijer (2005). 
The following model is used to analyze the indicators that affect renewable energy firm's profitability:

profit $_{i t}=\beta_{0}$ profit $_{i, t-1}+\beta_{1}$ size $_{i t}+\beta_{2}$ risk $_{i t}+$

$\beta_{3}$ age $_{i t}+\beta_{4}$ capital intensity $_{i t}+\beta_{5}$ growth $_{i t}+$

$\beta_{6} T G C_{i}+\beta_{7}$ electricity $_{i}+\beta_{8}$ market concentration $_{i}+$

$\beta_{9} G D P_{i}+\beta_{10}$ inflation $_{i}+\beta_{11} D 1_{i}+\beta_{12} D 2_{i+} \mu_{i t}$

The dynamic panel model is effective since the time-invariant variables such as TGC policy are included.

\section{Results and Discussion}

\section{Descriptive statistics and correlation results}

Table 1 represents the summary statistics of all variables that are included in the model. Regarding financial performance, the firms under examination seem to have large deviations throughout the period. The mean value of return on assets (ROA) is $-3.3 \%$, and the maximum value is $-31.3 \%$. The renewable energy firms in the EU exhibit various financial performance levels, indicating a high level of competitiveness. Also, the average Tobin's q value is 1.359 greater than 1 , which means that, in general, a renewable energy company has a high q score, which means a better investment opportunity.

The correlation matrix between key variables for the period 2004-2018 is shown in Appendix A. As it is seen, the correlation coefficients between regressors are less than the threshold level of 0.8 , meaning that the problem of multicollinearity is not present. Also, the variance inflation factor that is less than 10 in all models shows that all regressors in the model are free from collinearity.

\section{Results of regression analysis}

Tables 2 and 3 report the results from panel data regressions. The estimated results are reported in three types of models in order to add robustness. The OLS model is used in columns 1 to 3 , random effect GLS in columns 4-6 and, dynamic panel data models in columns 7-9. Return on assets (ROA) and Tobin's q are used as dependent variables while the variables of interest are divided into firm-specific factors, country-specific factors and macroeconomic factors. Models 1, 4, and 6 include only firm-specific factors and exclude other factors. Models 2 , 5 , and 7 include firm- and country-specific factors. Models
3, 6, and 9 incorporate firm-specific, country-specific and macroeconomic factors. The dynamic models seem to fit the panel data since we fail to reject the Hansen test of over-identifying restriction, and the number of instruments is less than the number of firms. Also, the results are consistent since the hypotheses of second-order autocorrelation could not be rejected meaning that there is no serial correlation in the residuals.

As Table 2 shows, the results are similar in the three models used to estimate the regression model, but the significance level for some variables is not delivered by the dynamic panel models, since the inclusion of a lagged dependent variable can absorb some variation in the alternative regression.

Consistent with the expectation, firm size in terms of market capitalization is consistently positive for all models, but the significance level varies from $1 \%$ to $5 \%$ under the system GMM estimator. The positive impact is related to the fact that larger firms are more profitable in the market and consequently have higher ROA and Tobin's q. Thus, the findings are consistent with the literature that suggests that the firm's size promotes the firm's financial performance (Asimakopoulos et al., 2009; Yazdanfar, 2013; Ruggiero and Lehkonen, 2017). The leverage ratio (risk) shows a positive effect on profitability and is significant only under the OLS model. In both random effect and system GMM, the effect of risk is not statistically significant. The growth of the firm has a substantial positive effect on profitability in line with Asimakopoulos et al. (2009), who support the hypothesis that growth enhances financial performance. The profitability of renewable energy firms is associated with a higher market concentration. The results can be explained by economic theory that firms tend to generate profit in case that they operate in a concentrated market. The support schemes seem to be somehow insignificant that is in line with Jaraite et al. (2015), who explain that renewable energy technologies need to develop through government support in order to take benefits from international trade.

The results in the dynamic models show that the current profitability of renewable energy firms is related to pastyear profitability. The effect of macroeconomic factors is found to be insignificant. Similarly, with prior studies by Eyraud et al. (2011), the effect of financial crises is harmful to profitability. 
Table 2. Determinants of profitability measured by ROA

\begin{tabular}{|c|c|c|c|c|c|c|c|c|c|}
\hline \multirow{2}{*}{ Explanatory variables } & \multicolumn{3}{|c|}{ OLS } & \multicolumn{3}{|c|}{$\mathrm{RE}$} & \multicolumn{3}{|c|}{ Dynamic } \\
\hline & (1) & (2) & (3) & (4) & (5) & (6) & (7) & (8) & (9) \\
\hline \multirow{2}{*}{$\mathrm{ROA}(\mathrm{t}-1)$} & & & & & & & $0.400^{* * *}$ & $0.249^{* * *}$ & $0.223^{\star \star \star}$ \\
\hline & & & & & & & $(0.108)$ & $(0.0673)$ & $(0.0584)$ \\
\hline \multirow{2}{*}{ Size (log) } & $0.0242^{\star \star \star}$ & $0.0172^{\star \star \star}$ & $0.0146^{\star * *}$ & $0.0371^{\text {** }}$ & $0.0342^{* * *}$ & $0.0290^{\star * *}$ & $0.0297^{* * *}$ & $0.0261^{* *}$ & $0.0226^{* *}$ \\
\hline & $(0.00317)$ & $(0.00362)$ & $(0.00359)$ & $(0.00541)$ & $(0.00571)$ & $(0.00491)$ & $(0.00892)$ & $(0.0103)$ & $(0.0103)$ \\
\hline \multirow{2}{*}{ Risk } & $0.184^{* * *}$ & $0.0765^{\star *}$ & $0.0941^{* * *}$ & 0.00994 & 0.00236 & 0.0200 & -0.0267 & -0.0720 & -0.0901 \\
\hline & $(0.0343)$ & $(0.0308)$ & $(0.0320)$ & $(0.0456)$ & $(0.0415)$ & $(0.0459)$ & $(0.0520)$ & $(0.0477)$ & $(0.0670)$ \\
\hline \multirow{2}{*}{ Age } & $0.000682^{* *}$ & $0.000788^{* *}$ & $0.00119^{* * *}$ & 0.00113 & 0.00156 & $0.00258^{* *}$ & -0.00110 & -0.000105 & -0.000401 \\
\hline & $(0.000345)$ & $(0.000377)$ & $(0.000410)$ & $(0.000865)$ & $(0.000971)$ & $(0.00120)$ & $(0.00191)$ & $(0.00303)$ & $(0.00312)$ \\
\hline \multirow{2}{*}{ Capital intensity (log) } & $-0.0206^{* \star *}$ & $-0.0128^{* \star *}$ & $-0.0130^{\star * *}$ & $-0.00553^{\star \star *}$ & $-0.00438^{* *}$ & $-0.00395^{\star *}$ & 0.00244 & 0.00686 & $0.00934^{* *}$ \\
\hline & $(0.00323)$ & $(0.00275)$ & $(0.00275)$ & $(0.00210)$ & $(0.00177)$ & $(0.00191)$ & $(0.00249)$ & $(0.00441)$ & $(0.00413)$ \\
\hline \multirow{2}{*}{ Growths } & -0.000855 & -0.000272 & -0.000703 & 0.000332 & 0.000996 & 0.000725 & $0.00186^{*}$ & $0.00441^{* \star *}$ & $0.00501^{* * *}$ \\
\hline & $(0.00204)$ & $(0.00211)$ & $(0.00200)$ & $(0.00136)$ & $(0.000832)$ & $(0.000851)$ & $(0.000972)$ & $(0.000817)$ & $(0.00118)$ \\
\hline \multirow{2}{*}{ TGC } & & $-0.0529^{* * *}$ & $-0.0592^{\star * *}$ & & -0.0880 & -0.0936 & & $-0.238^{\star *}$ & $-0.254^{* * *}$ \\
\hline & & $(0.0198)$ & $(0.0205)$ & & $(0.0655)$ & $(0.0636)$ & & $(0.0980)$ & $(0.0923)$ \\
\hline \multirow{2}{*}{ Electricity price (log) } & & -0.0268 & -0.0252 & & -0.0204 & -0.0103 & & 0.0516 & 0.0559 \\
\hline & & $(0.0280)$ & $(0.0335)$ & & $(0.0322)$ & $(0.0380)$ & & $(0.0487)$ & $(0.0483)$ \\
\hline \multirow{2}{*}{ Market concentration } & & $-0.0586^{* *}$ & $-0.0621^{* *}$ & & -0.0535 & -0.0668 & & -0.0516 & -0.0592 \\
\hline & & $(0.0244)$ & $(0.0272)$ & & $(0.0486)$ & $(0.0503)$ & & $(0.0924)$ & $(0.0854)$ \\
\hline \multirow{2}{*}{ GDP growth } & & & 0.456 & & & $0.413^{*}$ & & & $0.598^{* \star}$ \\
\hline & & & $(0.292)$ & & & $(0.233)$ & & & $(0.252)$ \\
\hline \multirow{2}{*}{ Inflation } & & & -0.0790 & & & -0.0985 & & & 0.512 \\
\hline & & & $(0.523)$ & & & $(0.460)$ & & & $(0.653)$ \\
\hline \multirow{2}{*}{ D1 } & & & $0.0614^{* * *}$ & & & $0.0397^{*}$ & & & -0.00295 \\
\hline & & & $(0.0215)$ & & & $(0.0205)$ & & & $(0.0157)$ \\
\hline \multirow{2}{*}{ D2 } & & & 0.000623 & & & -0.00590 & & & -0.0307 \\
\hline & & & $(0.0215)$ & & & $(0.0158)$ & & & $(0.0218)$ \\
\hline \multirow{2}{*}{ Constant } & $-0.433^{* * *}$ & $-0.311^{* * *}$ & $-0.304^{* * *}$ & $-0.506^{* * *}$ & $-0.468^{\star * *}$ & $-0.408^{\star * *}$ & $-0.332^{* \star *}$ & -0.0996 & -0.0357 \\
\hline & $(0.0513)$ & $(0.0748)$ & $(0.0843)$ & $(0.0855)$ & $(0.0881)$ & $(0.107)$ & $(0.113)$ & $(0.174)$ & $(0.159)$ \\
\hline Observations & 471 & 374 & 374 & 471 & 374 & 374 & 455 & 360 & 360 \\
\hline Number of firms & 41 & 40 & 40 & 41 & 40 & 40 & 41 & 40 & 40 \\
\hline Number of instruments & & & & & & & 32 & 32 & 36 \\
\hline $\mathrm{AR}(1)$ & & & & & & & 0.012 & 0.034 & 0.031 \\
\hline $\mathrm{AR}(2)$ & & & & & & & 0.338 & 0.586 & 0.682 \\
\hline Hansen test & & & & & & & 0.329 & 0.31 & 0.249 \\
\hline R-squared & 0.253 & 0.235 & 0.265 & 0.1242 & 0.1734 & 0.2063 & & & \\
\hline
\end{tabular}

Robust standard errors in parentheses; ${ }^{* *} p<0.01,{ }^{* *} p<0.05,{ }^{*} p<0.1$ 
Table 3. Determinants of profitability measured by Tobin's $q$

\begin{tabular}{|c|c|c|c|c|c|c|c|c|c|}
\hline \multirow{2}{*}{ Explanatory variables } & \multicolumn{3}{|c|}{ OLS } & \multicolumn{3}{|c|}{$\mathrm{RE}$} & \multicolumn{3}{|c|}{ Dynamic } \\
\hline & (1) & (2) & (3) & (4) & (5) & (6) & (7) & (8) & (9) \\
\hline \multirow{2}{*}{ Tobin's q (t-1) } & & & & & & & $0.296^{\star * *}$ & $0.219^{* \star *}$ & $0.209^{\star * *}$ \\
\hline & & & & & & & $(0.0431)$ & $(0.0710)$ & $(0.0675)$ \\
\hline \multirow{2}{*}{ Size (log) } & $0.0527^{\star \star}$ & $0.146^{\star \star \star}$ & $0.137^{\star \star \star}$ & $0.285^{\star \star \star}$ & $0.370^{* * *}$ & $0.343^{\star * *}$ & $0.237^{\star \star \star}$ & $0.294^{* * *}$ & $0.260^{\star \star *}$ \\
\hline & $(0.0259)$ & $(0.0296)$ & $(0.0287)$ & $(0.0818)$ & $(0.0830)$ & $(0.0743)$ & $(0.0827)$ & $(0.0696)$ & $(0.0867)$ \\
\hline \multirow{2}{*}{ Risk } & $-1.243^{* \star *}$ & -0.277 & -0.256 & -0.331 & 0.419 & 0.366 & -1.894 & 0.705 & $0.672^{*}$ \\
\hline & $(0.345)$ & $(0.219)$ & $(0.234)$ & $(0.459)$ & $(0.340)$ & $(0.331)$ & $(1.723)$ & $(0.494)$ & $(0.398)$ \\
\hline \multirow{2}{*}{ Age } & -0.00438 & $-0.00718^{*}$ & $-0.00679^{*}$ & -0.0176 & $-0.0402^{* * *}$ & $-0.0382^{* *}$ & -0.00961 & $-0.0566^{*}$ & $-0.0580^{*}$ \\
\hline & $(0.00523)$ & $(0.00409)$ & $(0.00404)$ & $(0.0119)$ & $(0.0128)$ & $(0.0149)$ & $(0.0242)$ & $(0.0318)$ & $(0.0302)$ \\
\hline \multirow{2}{*}{ Capital intensity (log) } & $0.0890^{* * *}$ & $0.0483^{*}$ & $0.0541^{*}$ & -0.0234 & -0.00205 & 0.00837 & -0.00260 & -0.00612 & 0.0118 \\
\hline & $(0.0277)$ & $(0.0284)$ & $(0.0288)$ & $(0.0200)$ & $(0.0192)$ & $(0.0198)$ & $(0.0592)$ & $(0.0349)$ & $(0.0267)$ \\
\hline \multirow{2}{*}{ Growth } & 0.0288 & 0.0294 & 0.0273 & 0.0199 & 0.0135 & 0.0138 & -0.0119 & -0.00526 & -0.00505 \\
\hline & $(0.0210)$ & $(0.0228)$ & $(0.0241)$ & $(0.0145)$ & $(0.0103)$ & $(0.0114)$ & $(0.0211)$ & $(0.0259)$ & $(0.0275)$ \\
\hline \multirow{2}{*}{ TGC } & & $0.656^{* * *}$ & $0.605^{* * *}$ & & $1.534^{* *}$ & $1.450^{* *}$ & & $2.578^{* *}$ & $2.612^{* *}$ \\
\hline & & $(0.175)$ & $(0.175)$ & & $(0.636)$ & $(0.620)$ & & $(1.110)$ & $(1.138)$ \\
\hline \multirow{2}{*}{ Electricity price (log) } & & -0.326 & 0.0146 & & $-0.801^{* * *}$ & -0.417 & & $-1.136^{* *}$ & $-0.699^{*}$ \\
\hline & & $(0.224)$ & $(0.284)$ & & $(0.280)$ & $(0.281)$ & & $(0.497)$ & $(0.400)$ \\
\hline \multirow{2}{*}{ Market concentration } & & 0.131 & $0.365^{*}$ & & -0.247 & -0.0787 & & -0.955 & -1.041 \\
\hline & & $(0.195)$ & $(0.211)$ & & $(0.762)$ & $(0.691)$ & & $(1.185)$ & $(1.278)$ \\
\hline \multirow{2}{*}{ GDP growth } & & & $5.178^{* *}$ & & & $3.618^{* * *}$ & & & 1.990 \\
\hline & & & $(2.138)$ & & & $(1.251)$ & & & $(2.757)$ \\
\hline \multirow{2}{*}{ Inflation } & & & $8.707^{\star *}$ & & & 1.278 & & & -5.225 \\
\hline & & & $(3.658)$ & & & $(2.304)$ & & & $(4.326)$ \\
\hline \multirow{2}{*}{ D1 } & & & -0.0679 & & & -0.0394 & & & -0.118 \\
\hline & & & $(0.202)$ & & & $(0.153)$ & & & $(0.244)$ \\
\hline \multirow{2}{*}{$\mathrm{D} 2$} & & & $-0.379^{* *}$ & & & $-0.245^{\star *}$ & & & -0.172 \\
\hline & & & $(0.164)$ & & & $(0.118)$ & & & $(0.228)$ \\
\hline \multirow{2}{*}{ Constant } & $1.005^{\star * *}$ & $-1.467^{\star \star *}$ & -0.795 & $-1.952^{\star *}$ & $-4.846^{* * *}$ & $-3.725^{* * *}$ & -1.346 & $-4.854^{* * *}$ & $-3.227^{*}$ \\
\hline & $(0.381)$ & $(0.525)$ & $(0.642)$ & $(0.911)$ & $(1.025)$ & $(0.976)$ & $(1.496)$ & $(1.395)$ & $(1.671)$ \\
\hline Observations & 470 & 373 & 373 & 470 & 373 & 373 & 439 & 344 & 344 \\
\hline Number of firms & 41 & 40 & 40 & 41 & 40 & 40 & 41 & 40 & 40 \\
\hline Number of instruments & & & & & & & 32 & 32 & 36 \\
\hline$A R(1)$ & & & & & & & 0.1934 & 0.2634 & 0.2582 \\
\hline $\operatorname{AR}(2)$ & & & & & & & 0.1566 & 0.2664 & 0.2845 \\
\hline Hansen test & & & & & & & 0.1455 & 0.1908 & 0.2432 \\
\hline R-squared & 0.099 & 0.158 & 0.192 & 0.022 & 0.113 & 0.13 & & & \\
\hline
\end{tabular}

Robust standard errors in parentheses 
Table 4. OLS regression analysis. Marginal effects on ROA and Tobin's q at minimum and maximum values of each independent variable

\begin{tabular}{|c|c|c|c|c|}
\hline \multirow[b]{2}{*}{ Variables } & \multicolumn{2}{|c|}{ ROA } & \multicolumn{2}{|c|}{ Tobin's q } \\
\hline & $\begin{array}{l}\text { Marginal effect at the } \\
\text { minimum level }\end{array}$ & $\begin{array}{l}\text { Marginal effect at the } \\
\text { maximum level }\end{array}$ & $\begin{array}{l}\text { Marginal effect at the } \\
\text { minimum level }\end{array}$ & $\begin{array}{l}\text { Marginal effect at the } \\
\text { maximum level }\end{array}$ \\
\hline \multirow{2}{*}{ Size } & $-0.1323^{\star \star *}$ & $0.0596^{* * *}$ & 0.2977 & $2.4623^{\star \star \star}$ \\
\hline & $(-0.0215)$ & $(-0.017)$ & $(-0.3705)$ & $(0.5600)$ \\
\hline \multirow{2}{*}{ Risk } & $-0.0851^{* * *}$ & $0.0517^{* * *}$ & $2.160^{* * *}$ & 0.0556 \\
\hline & $(-0.0164)$ & $(-0.0128)$ & $(0.337)$ & $(0.282)$ \\
\hline \multirow{2}{*}{ Capital intensity } & $0.1051^{* * *}$ & $-0.0184^{* * *}$ & 0.2828 & $1.8579^{* * *}$ \\
\hline & $(0.0184)$ & $(0.0257)$ & (0.1937) & $(0.268)$ \\
\hline \multirow{2}{*}{ Growth } & $-0.021^{* * *}$ & -0.1487 & $0.956^{* * *}$ & $5.700^{*}$ \\
\hline & $(0.0074)$ & (0.1017) & $(0.139)$ & $(2.909)$ \\
\hline \multirow{2}{*}{ TGC } & 0.00371 & $-0.1436^{\star * *}$ & $1.177^{\star \star \star}$ & $1.903^{\star * *}$ \\
\hline & -0.0047 & -0.2142 & $(0.152)$ & (0.2939) \\
\hline \multirow{2}{*}{ Electricity price (log) } & 0.0233 & $-0.084^{\star \star \star}$ & $1.959^{* * *}$ & $0.841^{* * *}$ \\
\hline & $(0.0154)$ & $(0.0173)$ & $(0.4134)$ & $(0.2361)$ \\
\hline \multirow{2}{*}{ Market concentration } & $-0.02622^{* *}$ & -0.0153 & $0.791^{* *}$ & $2.232^{\star \star \star}$ \\
\hline & $(0.0126)$ & $(0.0116)$ & $(0.2712)$ & $(0.6306)$ \\
\hline \multirow{2}{*}{ GDP } & $-0.0518^{* * \star}$ & -0.0200 & $0.9559^{\star \star}$ & $1.629^{\star \star \star}$ \\
\hline & $(0.0184)$ & (0.0139) & $(0.3698)$ & $(0.2636)$ \\
\hline \multirow{2}{*}{ Inflation } & -0.0215 & $-0.04662^{* *}$ & $1.139^{* * *}$ & $1.645^{\star \star *}$ \\
\hline & $(0.0139)$ & -0.0191 & $(1.645)$ & $(0.350)$ \\
\hline
\end{tabular}

Robust standard errors in parentheses; ${ }^{* *} p<0.01,{ }^{* *} p<0.05,{ }^{*} p<0.1$

Table 3 presents the results by using Tobin's $q$ as a measure of profitability and checking whether the results are similar as in the case when ROA is used as a measure of profitability. Consistent with prior findings, the effect of the size and lagged profitability is positive. However, the effect of risk on Tobin's q is positive, meaning that financial leverage increases financial performance. This finding supports the hypotheses that leverage fosters profitability, which is consistent with the study by Akhtar et al. (2012).
However, market concentration is not significant in long term profitability (Tobin's q). The effect of support schemes enhances Tobin's q showing that firms that operate under tradeable green certificate (TGC) are more profitable than FIT firms consistent with the finding of Jaraite and Kažukauskas (2013).

It is evident that the profitability of renewable energy firms is explained more from firm-specific factors rather than macroeconomic factors. 
Table 4 shows the OLS models' results of marginal effects of each explanatory variable on profitability instead of coefficients at the minimum and maximum levels of each model. For the first model in which size is an independent variable, the marginal effects of size on ROA are positive and statistically significant. The results emphasize that firm size is a determinant of financial performance. The marginal effects of risk on ROA seem negative at the minimum value of risk and positive at the maximum value of risk. This result shows that renewable energy companies are highly indebted, and an increase in the debt level implies an increase in their performance. The marginal effects of capital intensity on ROA behaviour are first positive and then negative. In the case of growth, it has a negative marginal effect on ROA at the minimum value, and after that, at the maximum value, it becomes positive, but it is not statistically significant. The marginal effects of growth and GDP on ROA are negative at their minimum values and they become positive, but not statistically significant. The marginal effects of electricity and inflation on ROA are negative at the maximum value, which means that an increase in inflation and electricity price reduces the firm performance.

Long-term performance is affected by the firm size as indicated by marginal effects of size on Tobin's q that is positive at the maximum level. The positive effects of leverage on long-term performance are at the minimum level, and after that they become positive but not statistically significant. The marginal effects of capital intensity become positive at the maximum level but are not statistically significant at the minimum value. The maximum and minimum marginal effects of growth on Tobin's q are positive and statistically significant, which means that the growth of companies enhances their long-term performance. The marginal effects of market concentration and GDP growth are positive and statistically significant at both their minimum and maximum values.

\section{Conclusions}

This paper empirically examines the determinants of firm profitability for renewable energy firms in the European Union countries for the period of 2004-2018. Furthermore, factors that affect profitability are divided into three groups, i.e., firm-specific factors, country-specific factors, and macroeconomic factors. The panel regression model is estimated in three ways, such as OLS, random effect, and the two-step system GMM methodology. The main findings of the paper are summarized as follows.

First, among firm-specific factors, it is evident that firm size and growth of the firm are statistically significant, and they foster profitability. This implies that larger renewable energy firms have a higher return on assets (ROA) and Tobin's q. Leverage is in a positive correlation with Tobin's q, which means that the long-term financial performance of renewable energy is strongly related to external funds to enlarge the investment in the company, in order to become more attractive for investors. The results of the study related to firm-specific factors provide critical information related to the specific factors affecting financial performance. These can help managers build management practices, to provide sustainable development for these companies.

Secondly, although EU countries operate under a common-energy policy, there are many differences across countries regarding regulation and market structure. To manage this difference across countries, country-specific factors related to the energy sector show that market concentration is positively associated with profitability (ROA). The effect of support schemes enhances Tobin's q showing that firms that operate under the tradeable green certificate (TGC) are more profitable than FIT firms. Since there is a difference in the profitability between firms that operate in countries that adopt different support schemes, policymakers need to pay attention to the support schemes effect. The improvement of support schemes and the cooperation between countries in constructing long term policies in renewable energy is crucial for their sustainable development. In the EU countries, it is suggested to extend investment in the renewable energy sector, in order to challenge the import-energy-dependency, and to build strong strategies in renewable energy to avoid any possible energy crises.

Third, macroeconomic factors do not seem to be determinants in profitability. The only significant factor is the financial crises that discourage financial performance.

The general policy implication of the findings of this study is that several economic and energy policies can be recommended. Thus, since the results show that renewable energy policies boost profitability in the long run, but 
not in the short run, it is recommended that the government and policymakers stimulate the global demand for renewable energy and also the interaction with other sectors of the economy that in turn enhance firm profitability. In addition, there is a need to foster investment programmes to maintain the targets related to renewable energy production imposed by the EU and provide energy with low carbon emissions. Furthermore, Energy Union should implement different support schemes for the new renewable energy companies, based on their performance. Also, this study provides information to managers related to factors that are determinants for renewable energy profitability. Since the size and growth of the firm are significant for short-term financial performance and size and leverage to promote long-term financial performance, managers could take these results

\section{References}

Abbasi, K., Jiao, Z., Shahbaz, M., and Khan, A. (2020). Asymmetric impact of renewable and non-renewable energy on economic growth in Pakistan: New evidence from a nonlinear analysis. Energy Exploration and Exploitation, 38(5), 1946-1967. https://doi.org/10.1177/0144598720946496

Agnolucci, P. (2007), "The effect of financial constraints, technological progress and long-term contracts on tradable green certificates", Energy Policy, Vol. 35 No.6, pp. 3347-3359. doi: 10.1016/j. enpol.2006.11.020. https://doi.org/10.1016/j.enpol.2006.11.020

Akhtar, S., Javaed, B., Maryam, A. and Sadia,H.(2012). "Relationship between Financial Leverage and Financial Performance : Evidence from Fuel and Energy Sector of Pakistan", European Journal of Business and Management,Vol. 4 No. 11, pp. 7-18.

Ali, A., and Alam, M. (2021). Profitability of energy sector companies of Saudi Arabia: Mutual analysis based on revenue and investment. Accounting, 7(3), 601-608. https://doi.org/10.5267/j. ac.2020.12.019

Anderson, B., Di Maria, C. and Convery, F. (2011), "Abatement and Allocation in the Pilot Phase of the EU ETS", Environmental and Resource Economics, Vol.48 No.1, pp. 83-103. https://doi. org/10.1007/s10640-010-9399-9

Apan, M. and İslamoğlu, M. (2018), “Determining the impact of financial characteristics on firm profitability: An empirical analysis on borsa Istanbul energy firms", WSEAS Transactions on Business and Economics, Vol. 15, pp. 547-559.

Apergis, N. and Sorros, J. (2014), "The Role of RandD Expenses for Profitability: Evidence from U.S. Fossil and Renewable En- into consideration while they are building strategic policy decisions. Manufacturing and administrative expenses should be controlled to increase their profits for their sustainability. Further research should be conducted to identify if there is any difference in the determinants of profitability between firms with different sub-sectors of the renewable energy industry such as wind, solar, geothermal, hydropower and biomass.

\section{Acknowledgements}

This research paper received support from the Research and Projects Grant Schemes of EPOKA University, under the International Research Project No. RP03004-2019.

ergy Firms", International Journal of Economics and Finance, Vol.6 No.3, pp. 8-15. https://doi.org/10.5539/ijef.v6n3p8

Arellano, M. and Bond, S. (1991), "Some Tests of Specification for Panel Data: Monte Carlo Evidence and an Application to Employment Equations", The Review of Economic Studies, Vol.58 No.2, pp. 277. https://doi.org/10.2307/2297968

Arellano, M. and Bover, O. (1995), "Another look at the instrumental variable estimation of error-components models", Journal of Econometrics, Vol.68 No.1, pp. 29-51. https://doi. org/10.1016/0304-4076(94)01642-D

Asimakopoulos, I., Samitas, A. and Papadogonas, T. (2009), "Firm-specific and economy wide determinants of firm profitability: Greek evidence using panel data”, Managerial Finance, Vol.35 No.11, pp. 930-939. https://doi. org/10.1108/03074350910993818

Bain, J. S. (1951), "Relation of profit rate to industry concentration: American manufacturing, 1936-1940", Quarterly Journal of Economics, Vol.65 No.3, pp. 293-324. https://doi. org/10.2307/1882217

Barakat, M. R., Elgazzar, S. H. and Hanafy, K. M. (2015), “Impact of Macroeconomic Variables on Stock Markets: Evidence from Emerging Markets", International Journal of Economics and Finance, Vol. 8 No.1, pp. 195. https://doi.org/10.5539/ijef.v8n1p195 Barney, J. B. (1991), “Firm Resources”, Journal of Management, Vol.17 No.1, pp. 99-120. https://doi.org/10.1177/014920639101700108

Blundell, R. and Bond, S. (1998), "Initial conditions and moment restrictions in dynamic panel data models", Journal of Econo- 
metrics,Vol.87 No.1, pp. 115-143. https://doi.org/10.1016/ S0304-4076(98)00009-8

Broadstock, D. C., Shu, Y. and Xu, B. (2011), "Do Macroeconomic Conditions Affect Firm-level Earnings Forecasts?", International Journal of Trade, Economics and Finance,Vol. 2 No.5, pp. 450-454. https://doi.org/10.7763/IJTEF.2011.V2.147

Capece, G., Cricelli, L., Di Pillo, F. and Levialdi, N. (2012) 'New regulatory policies in Italy: Impact on financial results, on liquidity and profitability of natural gas retail companies', Utilities Policy, Vol. 23, pp. 90-98. https://doi.org/10.1016/j.jup.2012.03.001

CEER (2017), Status Review of Renewable Support Schemes in Europe, Council of European Energy Regulators asbl. Available at: https://www.dewa.gov.ae/en/about-dewa/ news-and-media/pressand-news/latest-news/2017/09/dewa-awards-aed142-nillionlargest-csp.

Chadha, S. and Sharma, A. K. (2015),"Capital Structure and Firm Performance: Empirical Evidence from India", Vision: The Journal of Business Perspective, Vol.19 No. 4, pp. 295-302. https:// doi.org/10.1177/0972262915610852

Chang, T. H., Huang, C. M., and Lee, M. C. (2009). Threshold effect of the economic growth rate on the renewable energy development from a change in energy price: Evidence from OECD countries. Energy policy, 37(12), 5796-5802. https://doi. org/10.1016/j.enpol.2009.08.049

Chang, K., Zeng, Y., Wang, W. and Wu, X. (2019),"The effects of credit policy and financial constraints on tangible and research and development investment: Firm-level evidence from China's renewable energy industry", Energy Policy, Vol.130(January), pp. 438-447. https://doi.org/10.1016/j.enpol.2019.04.005

Chang, T. H., Huang, C. M. and Lee, M. C. (2009), "Threshold effect of the economic growth rate on the renewable energy development from a change in energy price: Evidence from OECD countries", Energy Policy, Vol.37 No.12, pp. 5796-5802. https:// doi.org/10.1016/j.enpol.2009.08.049

Cucchiella, F., Gastaldi, M. and Trosini, M. (2017), "Investments and cleaner energy production: A portfolio analysis in the Italian electricity market", Journal of Cleaner Production,Vol 142, pp. 121-132. https://doi.org/10.1016/j.jclepro.2016.07.190

Earnhart, D. and Lizal, L. (2007), "Effect of pollution control on corporate financial performance in a transition economy", European Environment, Vol. 17 No.4, pp. 247-266. https://doi. org/10.1002/eet.447

European Commission (2019), Renewable Energy Progress Report, COM (2019) 225 final. Available at: https://ec.europa. eu/commission/sites/beta-political/files/report-progress-renewable-energy-april2019_en.pdf.

Eyraud, L., Wane, A., Zhang, C. and Clements, B. (2011), "Who's Going Green and Why? Trends and Determinants of Green
Investment", IMF Working Paper WP/11/296. https://doi. org/10.5089/9781463927301.001

Fareed, Z., Ali, Z., Shahzad, F., Nazir, M. I. and Ullah, A.. (2017),"Determinants of Profitability: Evidence from Power and Energy Sector", Studia Universitatis Babe-Bolyai Oeconomica, Vol. 61 No.3, pp. 59-78. https://doi.org/10.1515/subboec-2016-0005

Filbeck, G. and Gorman, R. F. (2004), "The Relationship between the environmental and financial performance of public utilities", Environmental and Resource Economics, Vol. 29 No.2, pp. $137-$ 157. https://doi.org/10.1023/B:EARE.0000044602.86367.ff

Geroski, P. A., Machin, S. J. and Walters, C. F. (1997), “Corporate Growth and Profitability", The Journal of Industrial Economics, Vol. 45 No.2, pp. 171-189. https://doi.org/10.1111/14676451.00042

Goddard, J., Tavakoli, M. and Wilson, J. O. S. (2009) ,"Sources of variation in firm profitability and growth", Journal of Business Research, Vol. 62 No.4, pp. 495-508. https://doi.org/10.1016/j. jbusres.2007.10.007

Gökgöz, F. and Güvercin, M. T. (2018), “Energy security and renewable energy efficiency in EU", Renewable and Sustainable Energy Reviews, Vol 96, pp. 226-239. https://doi.org/10.1016/j. rser.2018.07.046

Gupta, K. (2017), “Do economic and societal factors influence the financial performance of alternative energy firms?", Energy Economics, Vol 65, pp. 172-182. https://doi.org/10.1016/j. eneco.2017.05.004

Hysa, E., Kruja, A., Rehman, N. U., and Laurenti, R. (2020). Circular economy innovation and environmental sustainability impact on economic growth: An integrated model for sustainable development. Sustainability, 12(12), 4831 https://doi. org/10.3390/su12124831

Issah, M. and Antwi, S. (2017), "Role of macroeconomic variables on firms' performance: Evidence from the UK", Cogent Economics and Finance, Cogent, Vol. 5 No.1, pp. 2332-2039. https://doi.org/10.1080/23322039.2017.1405581

Jaraitè, J., Karimu, A., Kažukauskas, A. and Kažukauskas, P. (2015),"Renewable Energy Policy , Economic Growth and Employment in EU Countries : Gain without Pain ?", CERE Working Paper, Vol. 7. https://doi.org/10.2139/ssrn.2615894

Jaraite, J. and Kažukauskas, A. (2013), "The profitability of electricity generating firms and policies promoting renewable energy", Energy Economics, Vol 40, pp. 858-865. https://doi. org/10.1016/j.eneco.2013.10.001

Khan, S. A. R., Yu, Z., Belhadi, A., and Mardani, A. (2020). Investigating the effects of renewable energy on international trade and environmental quality. Journal of Environmental Management, 272,1-7. https://doi.org/10.1016/j.jenvman.2020.111089 
Kogan, L. and Tian, M. (2012), Firm Characteristics and Empirical Factor Models: A Data-Mining Experiment Firm Characteristics and Empirical Factor Models: a Data-Mining Experiment, FRB International Finance Discussion Paper No. 1070. Available at: www.federalreserve.gov/pubs/ifdp/. https://doi. org/10.2139/ssrn.2182139

Kumar, S., Managi, S. and Matsuda, A. (2012), "Stock prices of clean energy firms, oil and carbon markets: A vector autoregressive analysis", Energy Economics, Vol 34 No.1, pp. 215-226. https://doi.org/10.1016/j.eneco.2011.03.002

Leitão, N. C., and Balsalobre-lorente, D. (2021). The Effects of Tourism, Economic Growth and Renewable Energy on Carbon Dioxide Emissions. In Strategies in Sustainable Tourism, Economic Growth and Clean Energy (pp. 67-87). Springer International Publishing. https://doi.org/10.1007/978-3-030-59675-0

Lester, J. P. and Lombard, E. N. (1990), “The comparative analysis of state environmental policy", Natural Resources Journal, Vol.30 No.2, pp. 301-319.

Lin, W.-L., Cheah, J.-H., Azali, M., Ho, J. A. and Yip, N. (2019), "Does firm size matter? Evidence on the impact of the green innovation strategy on corporate financial performance in the automotive sector", Journal of Cleaner Production, Vol 229, pp. 974-988. https://doi.org/10.1016/j.jclepro.2019.04.214

Li, B., Fan, X., Álvarez-Otero, S., Sial, M.S., Comite, U., Cherian, J. and Vasa, L., (2021), CSR and Workplace Autonomy as Enablers of Workplace Innovation in SMEs through Employees: Extending the Boundary Conditions of Self-Determination Theory. Sustainability, 13(11), p.6104. https://doi.org/10.3390/su13116104

Lindenberg, E. B. and Ross, S. A. (1981), "Tobin ‘ s q Ratio and Industrial Organization”, Journal of Business, Vol. 54 No.1, pp. 1-32. https://doi.org/10.1086/296120

Malik, I. A., Siyal, G.-A., Bin Abdullah, A., Alam, A., Zaman, K., Kyophilavong, P., Shahbaz, M., Baloch, T. U. and Shams, T. (2014),"Turn on the lights: Macroeconomic factors affecting renewable energy in Pakistan", Renewable and Sustainable Energy Reviews Vol38, pp. 277-284. https://doi.org/10.1016/j. rser.2014.05.090

McWilliams, A. and Siegel, D. (2000),"Corporate social responsibility and financial performance: Correlation or misspecification?", Strategic Management Journal, Vol. 21 No.5, pp. 603609. https://doi.org/10.1002/(SICl)1097-0266(200005)21:5<60 3::AID-SMJ101>3.0.CO;2-3

Marian, C., and Panait, M. (2019). Challenges Imposed by Renewable Energy Paradigms of the Romanian Economy from the European Perspective. Economic Insights - Trends and Challenges, 8(1), 49-60.

Mishra, S. and Suar, D. (2010), “Does Corporate Social Responsibility Influence Firm Performance of Indian Companies ?",
Journal of Business Ethics, Vol.95 No.4, pp. 571-601. https:// doi.org/10.1007/s10551-010-0441-1

Mohamed, M. K. T. (2014), "The effect of capital structure on profitability of Energy American Firms", International Journal of Business and Management Invention, Vol. 3 No.12, pp. 54-61. https://doi.org/10.4018/978-1-4666-6635-1.ch018

Molyneux, P. and Thornton, J. (1992),"Determinants of European bank profitability: A note", Journal of Banking and Finance, Vol.16 No.6, pp. 1173-1178. https://doi.org/10.1016/03784266(92)90065-8

Nanda, S. and Panda, A. K. (2018), "The determinants of corporate profitability: an investigation of Indian manufacturing firms", International Journal of Emerging Markets, Vol.13 No.1, pp. 66-86. https://doi.org/10.1108/IJoEM-01-2017-0013

Neves, M. E., Henriques, C., and Vilas, J. (2019). Financial performance assessment of electricity companies: evidence from Portugal. Operational Research, 1-49. https://doi.org/10.1007/ s12351-019-00504-1

Nishitani, K. and Kokubu, K. (2012), "Why Does the Reduction of Greenhouse Gas Emissions Enhance Firm Value? The Case of Japanese Manufacturing Firms", Business Strategy and the Environment, Vol.21 No.8, pp. 517-529. https://doi.org/10.1002/ bse.734

Pacesila, M., Burcea, S. G. and Colesca, S. E. (2016), "Analysis of renewable energies in European Union”, Renewable and Sustainable Energy Reviews, Vol. 56, pp. 156-170. https://doi. org/10.1016/j.rser.2015.10.152

Pakulska, T. (2021). Green energy in Central and Eastern European (CEE) countries: New challenges on the path to sustainable development. Energies, 14(4). https://doi.org/10.3390/ en14040884

Pätäri, S., Arminen, H., Tuppura, A. and Jantunen, A.. (2014), "Competitive and responsible? The relationship between corporate social and financial performance in the energy sector", Renewable and Sustainable Energy Reviews, Vol.37, pp. 142154. https://doi.org/10.1016/j.rser.2014.05.012

Paun, D. (2017), "Sustainability and financial performance of companies in the energy sector in Romania", Sustainability, Vol. 9 No.10, pp.1722-1732. https://doi.org/10.3390/su9101722

Phung, D. N. and Mishra, A. V. (2016), “Ownership Structure and Firm Performance: Evidence from Vietnamese Listed Firms", Australian Economic Papers, Vol. 55 No.1, pp. 63-98. https:// doi.org/10.1111/1467-8454.12056

Ramezani, C. A., Soenen, L. and Jung, A. (2002), “Growth, corporate profitability, and value creation", Financial Analysts Journal, Vol.58 No.6, pp. 56-67. https://doi.org/10.2469/faj.v58.n6.2486

Rashid, A. (2013),"Risks and financing decisions in the energy sector: An empirical investigation using firm-level data", En- 
ergy Policy, vOL 59, pp. 792-799. https://doi.org/10.1016/j. enpol.2013.04.034

Richter, M. (2013), "Business model innovation for sustainable energy: German utilities and renewable energy”, Energy Policy, Vol62, pp. 1226-1237. https://doi.org/10.1016/j.enpol.2013.05.038

Ruggiero, S. and Lehkonen, H. (2017), "Renewable energy growth and the financial performance of electric utilities: $A$ panel data study", Journal of Cleaner Production, Vol. 142, pp. 3676-3688. https://doi.org/10.1016/j.jclepro.2016.10.100

Seissian, L. A., Gharios, R. T. and Awad, A. B. (2018), "Structural and market-related factors impacting profitability: A cross sectional study of listed companies", Arab Economic and Business Journal, Vol.13 No.2, pp. 125-133. https://doi.org/10.1016/j. aebj.2018.09.001

Shah, I. H., Hiles, C. and Morley, B. (2018), "How do oil prices, macroeconomic factors and policies affect the market for renewable energy?", Applied Energy,Vol. 215, pp. 87-97. https:// doi.org/10.1016/j.apenergy.2018.01.084

Spanos, Y. E., Zaralis, G. and Lioukas, S. (2004), "Strategy and industry effects on profitability: Evidence from Greece", Strategic Management Journal, Vol.25 No.2, pp. 139-165. https://doi. org/10.1002/smj.369

Sueyoshi, T. and Goto, M. (2009), “Can environmental investment and expenditure enhance financial performance of US electric utility firms under the clean air act amendment of 1990?", Energy Policy,Vol. 37 No.11, pp. 4819-4826. https://doi. org/10.1016/j.enpol.2009.06.038

Sun, C., Zhan, Y., and Du, G. (2020). Can value-added tax incentives of new energy industry increase firm's profitability? Evidence from financial data of China's listed companies. Energy economics, 86, 1-14. https://doi.org/10.1016/j.eneco.2019.104654

Tobin, J. (1969), “A General Equilibrium Approach To Monetary Theory”, Journal of Money, Credit and Banking, Vol.1 No.1, pp.
15-29. Available at: http://www.jstor.org/stable/1. https://doi. org/10.2307/1991374

Verbruggen, A. and Lauber, V. (2012), "Assessing the performance of renewable electricity support instruments", Energy Policy,Vol. 45, pp. 635-644. https://doi.org/10.1016/j.enpol.2012.03.014

Wang, L., Li, S. and Gao, S. (2014), “Do greenhouse gas emissions affect financial performance? - An empirical examination of Australian public firms", Business Strategy and the Environment, Vol. 23 No.8, pp. 505-519. https://doi.org/10.1002/bse.1790

Wintoki, M. B., Linck, J. S. and Netter, J. M. (2012), “Endogeneity and the dynamics of internal corporate governance", Journal of Financial Economics, Vol.105 No.3, pp. 581-606. https://doi. org/10.1016/j.jineco.2012.03.005

Yazdanfar, D. (2013), "Profitability determinants among micro firms: Evidence from Swedish data”, International Journal of Managerial Finance, Vol.9 No.2, pp. 151-160. https://doi. org/10.1108/17439131311307565

Zhang, H., Li, L., Zhou, D. and Zhou, P. (2014), “Political connections, government subsidies and firm financial performance: Evidence from renewable energy manufacturing in China", Renewable Energy,Vol.63, pp. 330-336. https://doi.org/10.1016/j. renene.2013.09.029

Zhu, B. (2012), "The effects of macroeconomic factors on stock return of energy sector in Shanghai stock market", International Journal of Scientific and Research Publications, Vol.2 No.11, pp. 1-4.

The World Bank, World DataBank [Online]. Available:, 2019 [accessed December 2019], http://databank.worldbank.org/data/ home.aspx.

European Commission, Eurostat [Online]. Available:, 2019 [accessed December 2019], http://ec.europa.eu/eurostat/data/ database 